\title{
Retrospective study of clinico-pathological features of ovarian tumors
}

\author{
Sachin G. Vedpathak, Vaishali R. Korde Nayak*
}

Department of Obstetrics and Gynecology, MIMER Medical College, Talegaon Dabhade, Pune, Maharashtra, India

Received: 01 December 2017

Accepted: 30 December 2017

\section{*Correspondence:}

Dr. Vaishali R. Korde Nayak,

E-mail: drvaishalinayak@gmail.com

Copyright: ( $\odot$ the author(s), publisher and licensee Medip Academy. This is an open-access article distributed under the terms of the Creative Commons Attribution Non-Commercial License, which permits unrestricted non-commercial use, distribution, and reproduction in any medium, provided the original work is properly cited.

\begin{abstract}
Background: Ovarian masses are a frequent clinical diagnosis in general Gynecology. The aim of the present study was to assess risk factors, clinical features, CA 125 levels, histopathological diagnosis of the patients of all ovarian tumors that underwent surgical management between August 2013 to August 2017.

Methods: This was the retrospective study conducted in the department of Obstetrics and Gynecology in MIMER Medical College. We studied 50 patients those who underwent surgical management. Most of the patients $56 \%$ were in the reproductive age group, $28 \%$ patients were in the perimenopausal age group, $14 \%$ were in the postmenopausal age group. $82 \%$ patients were parous.

Results: Pain abdomen was most common symptom in $50 \%$ patients. Bilaterality of the tumor was common in malignant tumors. CA 125 was found to be increased more in malignant tumors. Most common co morbid condition was hypertension found in $12 \%$ patients. Most common ovarian tumor found was serous cystadenoma $34 \%$ and most common malignant tumors were serous cystadenoma carcinoma $16 \%$.

Conclusions: Out of all operated patients $11(22 \%)$ were malignant, $37(74 \%)$ were benign and $2(\%)$ were borderline tumors. Out of all malignant tumors $8(72 \%)$ were serous cysadenocarcinoma. It is difficult to always differentiate between malignant and benign tumors clinically. Analysis of risk factors and protective factors, thorough abdominopelvicbimanual examination, certain features on radiological imaging, presence of ascites and bilaterality, CA125 levels, helps increasing the accuracy of the diagnosis.
\end{abstract}

Keywords: CA 125, Clinical features, Histopathological diagnosis, Risk factors, Ovarian tumors

\section{INTRODUCTION}

Ovarian masses are a frequent clinical diagnosis in general Gynecology. They can be benign, malignant or functional ovarian cysts. Differentiation into these categories is not always possible clinically using imaging modalities \& various tumor markers. The final diagnosis mostly depends on histopathological examination. Thus, the management of such tumors must balance the risks of performing an operation for a benign lesion with the risk of not removing the malignant ovarian pathology. Benign masses are seen in premenopausal and majority of malignant masses are seen in postmenopausal women. ${ }^{1}$ Ovarian carcinomas represents $6^{\text {th }}$ most common cancer in the females and $4^{\text {th }}$ leading cause of cancer death in women. ${ }^{2}$ Symptoms may include abdominal pain, fatigue, bloating, constipation, urinary symptoms, weight loss etc. In ovarian malignancy these symptoms are of greater severity. The presenting symptoms can be acute and severe in case of torsion or rupture of the cysts. Presently Ovarian cysts rarely grow immense due to the fact that ultrasound scanning permits detection and appropriate treatment in time. ${ }^{3}$ But in rural set up, still we find huge ovarian masses: benign as well as malignant. The bimanual examination is the most practical method for adnexal mass screening. ${ }^{4}$ Transvaginal sonography measuring the ovarian volume also helps as a reliable screening test. 
Sonography, MRI and CT are the imaging techniques, which will help in delineating the nature of adnexal mass. Various tumor markers guide us about various histological types like CA-125 would be suggestive of epithelial cell tumors.

\section{METHODS}

This study is a retrospective observational study. The data of all ovarian masses operated in MIMER Medical College, Talegaon, Dabhade between August 2013 to August 2017 were obtained and analyzed.

After obtaining histopathology reports from Pathology Department the case records were obtained from record section. The inclusion criteria were all cases of ovarian masses, which were subjected for surgery. The total of 50 cases were obtained and studied. Collection of data included age at presentation, parity, symptoms, presence of comorbidity, tumor markers, histopathological reports. Collected data was tabulated and analyzed using suitable statistical tools.

\section{RESULTS}

50 patients were included in the retrospective study. Out of 50 patients $26(52 \%)$ were in the age group of $20-40$ years, $16(32 \%)$ were in the perimenopausal age group and $7(14 \%)$ patients were in the postmenopausal age group. The youngest patient was of 17 years old and the oldest was of 70 years. Malignant ovarian tumors were mostly found in perimenopausal and postmenopausal age group. Patients of all malignant tumors patients were of these age group.

Table 1: Age distribution.

\begin{tabular}{|llll|}
\hline Age group & $\begin{array}{l}\text { Benign } \\
\text { Tumors }\end{array}$ & $\begin{array}{l}\text { Malignant } \\
\text { Tumors }\end{array}$ & $\begin{array}{l}\text { Borderline } \\
\text { Tumors }\end{array}$ \\
\hline$<20$ years & 1 & 0 & 0 \\
\hline 20-40 years & 26 & 0 & 0 \\
\hline Perimenopausal & 7 & 7 & 2 \\
\hline Post-menopausal & 3 & 4 & 0 \\
\hline
\end{tabular}

Most ovarian cysts are asymptomatic and are found incidentally on routine pelvic examinations or during USGs for another indication. But in the present study the most common symptom was pain in abdomen in 25 (50\%) patients. Severe dysmenorrhea was indicative of endometriosis with endometrium and dull ache or pressure may be due to stretching of ovarian capsule.

Table 2: Parity distribution.

\begin{tabular}{ll} 
Parity & No. of patients \\
Parous & 41 \\
\hline Nulliparous & 9 \\
\hline
\end{tabular}

$4(8 \%)$ women presented with severe pain in abdomen, vomiting and tachycardia s/o torsion. 14 (28\%) patients presented with mass per abdomen, 4 (8\%) with vague discomfort and 3(6\%) were asymptomatic patients. In advanced ovarian malignancies women noted increased abdominal girth from ascites or from enlarged ovary.

Table 3: Symptom wise distribution of patients.

\begin{tabular}{|ll|}
\hline Symptoms & No. of patients \\
\hline Asymptomatic & 3 \\
\hline Mass per abdomen & 14 \\
\hline Pain in abdomen & 25 \\
\hline Acute and severe pain (torsion) & 4 \\
\hline Vague discomfort & 4 \\
\hline
\end{tabular}

Ovarian mass presented as right sided ovarian mass in 25 (50\%) patients; in $12(24 \%)$ patients it was left sided mass. Out of $14(28 \%)$ patients presented with bilateral masses, 7 were benign, 5 were malignant and 2 cases were reported as borderline tumors. Most 5 (45\%) of all malignant tumors (11) were found to be bilateral.

Table 4: Laterality of the Ovarian mass.

\begin{tabular}{|llll|}
\hline Laterality & $\begin{array}{l}\text { Benign } \\
\text { Tumors }\end{array}$ & $\begin{array}{l}\text { Malignant } \\
\text { Tumors }\end{array}$ & $\begin{array}{l}\text { Borderline } \\
\text { Tumors }\end{array}$ \\
\hline Right & 22 & 3 & 0 \\
\hline Left & 9 & 3 & 0 \\
\hline Bilateral & 7 & 5 & 2 \\
\hline
\end{tabular}

In the present study $8(16 \%)$ patients had CA 125 raised high that is $>200 \mathrm{U} / \mathrm{ml}, 9(18 \%)$ patients had CA 125 between $35-200 \mathrm{U} / \mathrm{ml}$ and $33(66 \%)$ patients were having CA125 <35U/ml. Out of all malignant tumors $10(90 \%)$ patients having raised CA-125 levels. 5 (13\%) patients out of all benign tumors also had raised CA-125 levels.

Table 5: CA 125 levels.

\begin{tabular}{|llll|}
\hline $\begin{array}{l}\text { CA 125 Levels } \\
\text { (U/ml) }\end{array}$ & $\begin{array}{l}\text { Benign } \\
\text { Tumors }\end{array}$ & $\begin{array}{l}\text { Malignant } \\
\text { Tumors }\end{array}$ & $\begin{array}{l}\text { Borderline } \\
\text { Tumors }\end{array}$ \\
\hline$<35$ & 32 & 1 & 0 \\
\hline $35-200$ & 5 & 4 & 0 \\
\hline$>200$ & 0 & 6 & 2 \\
\hline
\end{tabular}

In the study $39(78 \%)$ patients were having no comorbid condition, 4 (8\%) patients were having hypothyroidisum, $1(2 \%)$ patient had diabetes mellitus, $6(12 \%)$ patients had hypertension.

Table 6: Comorbidity.

\begin{tabular}{|ll|}
\hline Comorbidity & No. of patients \\
\hline No comorbidity & 39 \\
\hline Hypothyroidism & 4 \\
\hline Diabetes Mellitus & 1 \\
\hline Hypertension & 6 \\
\hline
\end{tabular}

In the study most, common histopathological diagnosis was serous cystadenoma $17(34 \%)$ patients, $11(22 \%)$ 
patients had diagnosis of simple ovarian cyst, 7 (14\%) patients had diagnosis of mature cystic teratoma, 8 (16\%) patients had a diagnosis of Serous cystadenomacarcinoma.

Table 7: Histopathology.

\begin{tabular}{|l|l|}
\hline Histopathology report & No. of patients \\
\hline Simple ovarian cyst & 11 \\
\hline Mature cystic teratoma & 7 \\
\hline Ruptured corpusleauteal cyst & 1 \\
\hline Serous cystadenoma & 17 \\
\hline Tuberculous tub ovarian mass & 1 \\
\hline Borderline serous neoplasam & 2 \\
\hline Serous cystadenoma carcinoma & 8 \\
\hline Mucinous cystadenomacarcinoma & 2 \\
\hline Dysgerminoma & 1 \\
\hline
\end{tabular}

\section{DISCUSSION}

Ovarian tumors have varied age wise, clinical, morphological, histological presentation. In the present study most of the benign tumors $26(52 \%)$ were seen in age group of 20-40 years and most of the malignant tumors were seen in perimenopausal 7 (63\%) and menopausal $4(36 \%)$ age group. Scully et al so observed around $75 \%$ of the ovarian tumors in reproductive age group. ${ }^{5}$ In Ruchika et al study $77.3 \%$ malignant tumors were found in reproductive age group and $13.6 \%$ were found in postmenopausal age group. ${ }^{6}$ Of all patients 4 $(8 \%)$ having malignant tumor were of postmenopausal age group.

In the present study out of 9 nulliparous patients $3(33 \%)$ had benign ovarian tumor while $6(67 \%)$ patients had malignant ovarian tumor. Thus, nulliparity increases the risk of malignant tumor. ${ }^{7}$

In the present study most, common presenting symptom was pain abdomen in $25(50 \%)$ patients. $14(28 \%)$ patients had complaints of distention/mass per abdomen, $4(8 \%)$ patients had vague abdominal discomfort and 3 (6\%) were asymptomatic. Dramatic presentation with tossing in bed, vomiting, tachycardia was seen in $4(8 \%)$ patients presented with torsion. Ovarian malignancies are said to be 'silent killers' that they lack appreciable signs and symptoms. But we found that patients are actually symptomatic for several months before the diagnosis.

The difficulty was in distinguishing these symptoms from those that women normally have. In malignant tumours we had pain in abdomen and distention / mass in abdomen as the common symptoms. In study by Ruchika et al $73 \%$ of the malignant tumors presented with abdominal distension, $52 \%$ with the pain, 21.5 with the constitutional symptoms, $10.5 \%$ with the gastrointestinal symptoms. ${ }^{6}$ In study done by Yogambal and Arunalata pain abdomen was commonest symptom that is $66.92 \%$ followed by mass abdomen $28.11 \% .^{2}$ Rashid et al had commonest symptom as pain (50\%), followed by abdominal mass/distension (37\%). ${ }^{8}$ In other study done in 2015 in Saudi Arabia most common symptom was abdominal pain. ${ }^{9}$

Tumor markers are proteins produced by tumor cells or the body response to tumour cells. Of all markers CA 125 which is commonly used is secreted by the mesothelial cells of peritoneal, pericardial and pleural linings. It is often elevated in epithelial tumors. But it is not a tumorspecific antigen as it is also found raised in fibroids, endometriosis, adenomyosis, salpingitis and $1 \%$ of healthy individuals. In the present study $8(16 \%)$ patients had CA125 levels >200U/ml, $9(18 \%)$ patients had CA125 levels in the range of $35-200 \mathrm{U} / \mathrm{ml}, 33(66 \%)$ patients had CA125 levels $<35 \mathrm{U} / \mathrm{ml}$. Most of the patients with raised CA125 levels were having epithelial ovarian tumors. So CA125 is having more sensitivity but lesser specificity for epithelial tumors. CA125 antigen has become standard component for diagnosis of advanced ovarian tumors. ${ }^{10}$ Normal levels of CA125 is $<35 \mathrm{U} / \mathrm{ml} .{ }^{11}$

In the present study most common associated comorbid condition was hypertension, others were hypothyroidism and diabetes mellitus.

In this study, $37(74 \%)$ were benign tumors $11(22 \%)$ tumors were malignant and $2(4 \%)$ were borderline serous tumors. In study done by Soumini $G$ et al 84.16 patients were neoplastic and nonneoplastic were $15.84 \% .{ }^{12}$ In Garg R et al $44 \%$ patients were malignant. ${ }^{6}$ We found serous cystadenoma as the most common histopathological type of ovarian tumor found in 17 (34\%) of patients, simple cyst found in $11(22 \%)$ patients, mature cystic teratoma found in $7(14 \%)$, and serous cystadenomacarcinoma in $8(16 \%)$ patients.

\section{CONCLUSION}

Out of all operated patients $11(22 \%)$ were malignant, 37 $(74 \%)$ were benign and $2(\%)$ were borderline tumors. Out of all malignant tumors $8(72 \%)$ were serous cysadenocarcinoma. It is difficult to always differentiate between malignant and benign tumors clinically. Analysis of risk factors and protective factors, thorough abdomino-pelvicbimanual examination, certain features on radiological imaging, presence of ascites and bilaterality, CA125 levels, helps increasing the accuracy of the diagnosis.

Funding: No funding sources

Conflict of interest: None declared

Ethical approval: The study was approved by the Institutional Ethics Committee

\section{REFERENCES}

1. Berek JS, Longacre TA, Friedlander M. Ovarian, fallopian tube and peritoneal cancer: In Berek and Novaks Gynecology, $15^{\text {th }}$ ed. Philadelphia. PA: Lippincott Williams and Wikins;2015:1350-1416. 
2. Yogambal M. Arunalatha P, Chandramouleeswari K, Palaniappan V. Ovarian tumors-incidence and distribution in a tertiary referral centre in south India. IOSR J Dent Med Sci. 2014;13(2):74-80.

3. Bhasin SK, Vijaykumar, Rajkumar. Giant ovarian cyst: a case report. JK Sci. 2014;16(3).

4. Kumar P. Malhotra Ni Jeffcoates. Principles of Gynaecology. Jaypee Brothers Medical Publishers (P) Ltd; 7th edition; 2008.

5. Scully RE, Young RH, Clement PB, In: Scully RE, Young RH, Clement PB, eds. Atlas of tumor pathology of the ovary, maldeveloped gonads, fallopian tube and broad ligament. $3^{\text {rd }}$ edition. Fasciele 23. Armed Forces Institute of Pathology. Washington DC; 1998:27-50.

6. Ruchikagarg. A clinicopathological study of malignant ovarian tumors in India. J South Asian Federation of Menopause Societies. 2014;2(1):9-11.

7. Purdie DM, Bain CJ, Siskind V, Webb PM, Green AC. Ovulation and the risk of epithelial ovarian cancer. Int J Cancer. 2003;104(2):228-32.

8. Rashid S, Sarwar G, Ali A. clinicopathological study of ovarian cancer. Department of radiotherapy and oncology. Sir Gangaram hospital and Mayo Hospital Lahore. J Park Med Arroe. 1998;36:117-25.

9. Hassan S. Abduljabbar. Review of 244 cases of ovarian cysts. Saudi Med J. 2015;36(7):834-8.

10. Markman M. Optimizing primary chemotherapy in ovarian cancer. Hemtol Oncol Clin North Am. 2003;17:957-68.

11. Bast RC Jr, Klug TL, St John E, Jenison E, Nilloff $\mathrm{JM}$, Lazarus $\mathrm{H}$, et al. A radioimmunoassay using a monoclonal antibody to monitor the course of epithelial ovarian cancer. $\mathrm{N}$ Engl J Med. 1983;309:883-7.

12. Gangaraju S, Sarella LK, Chaveli L, Gurugubelli S. Scenario of ovarian mass lesions at a teaching hospital in Andhra Pradesh, India. IJRCOG. 2017;4(4):982-9.

Cite this article as: Vedpathak SG, Nayak VRK. Retrospective study of clinico-pathological features of ovarian tumors. Int J Reprod Contracept Obstet Gynecol 2018;7:618-21. 